\title{
Globalization and World Economic Crisis: Antinomy of Fukuyama's End of History and the Last Man
}

\author{
Manpa'a Aliyu Musa, Anthony Israel Rufus and Hassana .I. Waziri \\ Department of Public Administration University of Maiduguri \\ Department of Political Science University of Maiduguri
}

\begin{abstract}
The end of phenomenal cold war in the 1990s between western and eastern Europe, following the dramatic exit of soviet union from global political theatre saw the emergence of new world order and the truimphism of capitalism and liberal democracy even among the countries hither to under the shackles of dictatorial regimes. These international trends in no small way reinforced the "third wave" of global capitalist democracy revolution. At the apex of the epoch of deepening globalization, there exist the general belief and tendency particularly among the western inspired conventional wisdom that with the collapse of soviet union, socialism has demised giving room for the establishment of capitalism and liberal democracy as the only arrangement under which human aspiration and prosperity became tenable. The loudest voice that gained global currency is Fukuyama's end of history and the last man. It is against this background that the forms and content of the paper focuses on the global economic crisis in the deepening epoch of globalization as an antinomy to the Francis Fukuyama's postulation "end of history and the last man", and since the postulation fall within the context of Neo-liberal theory. The paper is based on documentation and analysis techniques. The paper established that the neo-liberal assumption that global capitalism and internationalization of liberal democracy marked an end state of human ideological evolution is a fallacy and that the market forces logic in allocation of resources and value as unscientific. This paper also revealed that the neo-liberal conventional wisdom is a form of post modern jingoism serving the political purpose of economy of encouraging one to associate or confuse the term "globalization" with globalizing negative impact on human development.

The study conclude that the neo-liberal theory of international relations as voiced out in Fukuyama's end of history and the last man, has left outstanding parameters which make the basis of their claim that global capitalism and internationalization of liberal democracy is an end state of human ideological evolution as not only tautological, but lack sound scientific reasoning resulting into antinomies or contradictions.
\end{abstract}

\section{Introduction}

The end of phenomenal cold war in the early 1990s between the Western and Eastern Europe following the dramatic exit of Soviet Union from global political theatre saw the emergence of New World Order (unipolar) and the triumphalism of capitalism and liberal democracy, even among countries hitherto under the shackles of dictatorial regimes. The development has made global capitalism and its political corollary liberal democracy to become the dominant and most important Post-Cold War agenda, which led to the massive adoption of capitalist democratic values and structure by many countries of the world.Within the Global context, the globalization of capitalism and the liberal democracy could better be situated within the purview of the postcold war realities of the demise of the Eastern bloc on one hand and triumph of international capitalism (Globalization) and its political corollary liberal democracy on the other.

These two factors put together had provided impelling environment and inevitable contingency; especially on the part of the authoritarian leaders of both military and one party socialist states to assent to capitalism and multi-party democratic system albeit, reluctantly (Tar, 1999).

In a more specific term, the eruption of the crisis of governance in the old Eastern bloc and its eventual demise in the early 1990s had accelerated the tempo of global capitalism and democratization in the sense. This wave was further, accentuated by pro-democracy development inspired by the triumphant unipolar western powers spear headed by American hegemony, which left the world in general and third world countries in particular with no alternative than to dance to their tune.The first and non-negotiable political conditionality of the hegemony and the global-financial, institution (World Bank, IMF etc) is the adoption of democracy (liberal) and good governance based on their perception which the third world countries were compelled to obey.These international trends in no small way reinforced the "third wave" of global capitalist democracy revolution (Diamond, 1992; Huntington, 1991; Bashir, 1992).

At the apex of the epoch of deepening globalization, there exist the general belief and tendency particularly, among the western inspired conventional wisdom that with the collapse of Soviet Union, socialism 
has demised giving room for the establishment of capitalism and liberal democracy as the only global arrangement under which human aspirations, development and prosperity became tenable.

The assumption is not new but, is an affirmation of the early modernization theory, re-echoed in the neo-liberal approach which found expression in the scholarly works of Samuel P. Huntington, Henry Kissinger, and Francis Fukuyama. The loudest voice among these scholars that gained global currency is the Fukuyama's end of history and the last man.

Fukuyama (1992) portrays capitalism and liberal democracy as the end of history and the last man. Although here, he did not mean history in it's conventional sense but 'the emergence of global capitalism and liberal democracy" is an end state in human ideological evolution. Meaning there will be no better option to capitalism and liberal democracy.

Time and space not permitting elaboration, suffice to say that capitalism as a political cum economic arrangement in which means of production, distribution and exchange are privately owned and controlled by individuals and corporate organizations is anchored not only on the praxis of laissez-fairism and nongovernmental intervention, but rather that market forces of demand and supply allocate resources and value. Whereas it's political corollary liberal democracy on the premise of democratic ethos notably multi-partism, transparency and accountability, popular sovereignty, periodic free fair election and above all, upholding the rule law (Gray, 2002).

Be that as it may, it is truism that global capitalism and liberal democracy had triumphed and some group of individuals and countries have attended appreciable level of prosperity under it (Malaysia, Indonesia, China, Japan etc). However, contemporary reality occasioned by the global economic recession which began first in the United States of America following the collapse of Lehman brothers, AIG and other Wall Street institutions was followed suit by financial and economic crisis across the entire globe, especially among the countries of European Union. The decision of these western nations to use tax payer's money for bail out is an antinomy to the Fukuyama's end of history and the last man. It is against the foregoing exigencies therefore, that the forms and content of this paper focus on the Global Economic Crisis in the deepening epoch of Globalization as an antinomy (contradiction) to Fukuyama's preposition of the end of history and the last man. However, since Fukuyama's postulation fall within the context of neo-liberal theory, the paper is a critique of the neo-liberal theory of international relation which glorifies Global Capitalism and internationalization of liberal democracy.

The paper is patterned along four key segments. The first part which is the foundation contains the general introduction, conceptual and theoretical construct of global capitalism (Globalization) and liberal democracy. The second segment presents background to the economic crisis and the main postulate of Neoliberal theory and Fukuyama's end of history and last man. The third section is critique of the neo-liberal theory as expressed in the Fukuyama's end of history, and the fourth and last segment is the summary and conclusion.

\section{CONCEPTUAL AND THEORETICAL CONSTRUCT ON GLOBAL CAPITALISM (GLOBALIZATION) AND LIBERAL DEMOCRACY}

Antimonies and contradictions abound both within and among scholars on the concepts as well as process of globalization. It is pertinent, to state that the concepts of globalization conjure up different images in the minds of scholars. This makes the conceptualization of the subject not only difficult but ambiguous to the extent that a better understanding of the concept and process of globalization can be achieved contextually or subject specific.

That is why kly (1999) succinctly put it:

A casual examination of the popular concept of globalization suggest that the term may possess more fad or fashion than substance other than its utility as would be countenanced by the descriptive of political science. Assuming it to be more than a policy gimmick, an examination of this popular concept from the perspective of other discipline posses the dilemma of first, determining exactly what is to be analyzed.

Similarly Paul (2008) avers that Globalization refers to many processes in the economic, political and social spheres. However, it is within the context of the economic arena where the popular idea of globalization takes root and either horrified or delights the imagination of most people. Unfortunately, it is difficult to understand the process by which it occurs.

In the words of Thomas Friedman (2001: ):

Globalization is the inexorable development of markets, nations, state and technologies to a degree never witnessed before in a way that is enabling individual corporations and Nation States to reach around the world, further, faster, deeper and cheaper than ever before and in a way that is enabling the world to reach into individuals, corporation and Nation State farther, faster, deeper, and cheaper than ever before. 
By and large, the most appropriate place to begin the understanding of globalization as economic and cultural phenomena is in particular sense of development concerning the concrete structuration of the world as a whole. Because it captures the idea that human ways of seeing the world are becoming more similar. As Boli and Thomson (1997:173) explain, in defining globalization, principle and purposes are cognitively constrimentical in similar way throughout the world. Juxtaposed, Globalization has been used by Robertson (1995) and Kraidy (1999) to refer to the interface between the process of globalization and localization or cultural balkanization. The term emphasizes that both global and local cure are inherently hybrid and that both globalization and localization involve process in which hybridization occurs. Keohane and Nye (1980) modify the realist school of international relations which originally focused on the power of Nation State as a source of study. According to them, globalization leads to a complex interdependence among those who pursue their own interests, on the global playing ground. The argument is that the military and security no longer dominate international politics but economics and social issues play an increasingly important role in international relation.

Skler's (1995) Marxian analysis of globalization argued that the principal forces behind the adoption of global practices are multinational corporations and national elite attuned to global trends. According to this view globalization creates contradictory process, the generation of wealth and globalization marginally that stimulate migration within and between countries and towards global cities (Sasseria and Appah 1998).

In contemporary context, globalization compresses time, space, relationships, creating what Castels called the Space of Tours., which means intense network interaction among geographically dispersed groups, occurring in the immediate "real time". Accordingly, everyday life human interaction communicated over distances now became routinized, indeed even 'natural' globally integrated sector (Castels, 1996).

What the above view depicts is that the world has now been miniaturized and transformed into global village making nonsense of distance and time through micro-electronic revolution and the global network production, cultural and social, which drive the depriving and geographical reach of geographical process.

Indeed, it is a fact that global economic integration and time space compression across increasing porous national boundaries exist only because of rapid innovation cycle, constantly generated by the electronic informational infrastructure, which in a multi-layered web of firms, service and networks that is a transnational computer networks, micro-electronic driven production, online financial system, fast and cheap air travels and satellite based telecommunication system, like the multi-satellite iridium system, which link any geographical location on the globe with immediate direct satellite access to the global communication and information system.

It must be acknowledged at this particular juncture, that critics often conflict globalization process driven by the micro-electronic revolution with neo-liberal economic and social policies implemented by the economic and political elite from dominant states and multinational organization (Hirst and Thompson, 1996). While neo-liberalism is the hegemonic policy in this conjuncture, the microelectronic revolution is the technological forces that render the neo-liberal version of globalization a feasible economic and social policy. However, since the Asian financial crisis, this position has been increasingly questioned by less dogmatic and more realists economists such as Kingman and Sachs (Paul, 2003). It is within the realm of this critical perspective that we are to look at globalization throughout this paper i.e. global capitalism or in the words of Kly, (1999) Globalism. When for purpose of clarity he divided the popular concept of globalization into two parts with the first part termed globalization in reference to the natural consequences of global development and the second as globalism, the attempt to globalize an ideological and socio-economic system by attaching or associating them with the natural demands and consequences of natural globalization by America.

It is within the above context that Kly (1999) conceptualizes globalization as entailing not systems concepts, ideologies and present politics as necessary factors in animating population increase, rapid technological advances, industrialization etc but also connotes that the western economic system and its ideological apparatus and policies were the sole and inevitable system and ideologies for the effective management of this inescapable global process.

\section{Theoretical Construct on Global Capitalism}

Global capitalism otherwise known as globalization is not a recent development but an enduring process that has become part and parcel of human society generally. It is a long historical process that originated in the $15^{\text {th }}$ century though never a linear process for its impact is always mediated by specific, historically situated local institution (Paul 2008). For us to be able to situate the growth and development of globalization, it is germane to resort to philosophical position on the subject in respect to the issue under discourse. Philosophers are divided into two broad categories based on their shared characteristics of their variant albeit, in some case similar to theoretical construct.

The first category is the western inspired conventional wisdom, comprising scholars of modernization and neo-liberal theory represented by scholars such as Rostow, Mcclelland, Huntington, Kissenger and Fukuyama among others. The dominant theoretical thrust of this group is that the only route to modernity is the 
neo-liberal democratic path under global capitalism. Therefore any society wishing to realize its aspiration to the desired state should democratize in the western sense and liberalize its economy. In this contemporary era this western inspired conventional thinking received the most lucid and precise expression in the treatise of Francis Fukuyama's end of history and the last man (1992) following the demise of Soviet Union and the emergence of Commonwealth of Independent State (CIS) where Fukuyama boasted that globalization is the end of human ideological evolution. Therefore the triumphalism of capitalism and liberal democracy is the end of history and the last man.

\section{The Marxian Political Economy}

Hinged on the Marxian-philosophical praxis which is represented by the works of scholars, majority of third world background, Marx began indeed by acknowledging the power of global capitalism and predicted accurately the emergence of globalization. Under uni-polar arrangement, when he stated inter alia that capitalism will one day incorporate the whole world into the orbit of global capitalist system before exploding, because of inherent contradiction (Exploitation and inequality) upon which it was built and suggested that the better alternative to development is socialism based on socialistic democratic principles as contained in the communist manifesto.

It should be noted that the interface between two theoretical construct is the sources of the antinomy between globalization and global economic crisis.

\section{THE MAIN POSTULATE OF NEO-LIBERAL THEORY AND FUKUYAMA'S END OF HISTORY AND THE LAST MAN}

The neo-liberal theory of international relation is the western inspired conventional thinking which is an off shot of modernization theory, albeit slightly differentiated in approach the forms and content of this two theoretical construct shared the intent (this neo-liberal school of thought is represented by the work of scholars such as Henry Kessinger, Samuel P. Huntington and Francis Fukuyama among others. With regards to the popular concept of globalization is that global capitalism and liberal democracy is the only sure way of attaining human aspiration to development and prosperity.

No where does this neo-liberal theory of international relations find better expression than in the book, "End of History and the Last Man" by Francis Fukuyama and propelled to dominance by the failure of the Soviet Union and the consequent unrestrained credibility facility given to the output of the IMF, WTO, the World Bank, International Corporation and the United States International Economic policies.

According to Fukuyama (1992) the emergence of globalization (New World Order) that saw the triumphalism of capitalism and Internationalization of liberal democracy had signified the end of history and the last man.

Meaning that the only route to modernity is the neo-liberal democratic path under global capitalism therefore globalization is the end to human ideological evolution.

What the above imply is that western liberal capitalist concept as represented by the United States of America has won and proved itself to be right; it is now the inevitable and decisive direction to all future socioeconomic development, it is in this sense that history is purported to have ended meaning that all theories that questioned the liberal western capitalist formula for global economic development have been proved by history to be wrong.

Concomitantly, further consideration should only be given to those theories, which animated and are espoused by liberal western oriented organizations such as IMF, International Corporations and the US government etc. In short it is a new beginning, a new world order in which natural globalization process and products are to be oriented and employed towards the fulfillment of western globalizing policies.

\section{ANTINOMY TO FUKUYAMA'S END OF HISTORY AND THE LAST MAN}

This discourse on how Global Economic crisis constitutes an antinomy to Fukuyama's end of history and the last man must surely begin with operational definition of the word antinomy.

The term antinomy donates different meaning to different people. It could be a contradiction in a law or between two equal binding laws (Chetham Miso 1592). It is also used in reference to a contradiction (Obs: 1647; Milton 1847, Taylor 1649 and Deus Justif 1656). In another perspective antinomy means a reasonable paradox intellectual contradictoriness (Kant 1802, Robinson 1857 and Wake 1877).

Viewed from which ever perspective therefore it still contain some elements of absurdity and contradiction. Therefore antinomy in this paper is used to mean contradiction.

Specifically, the antinomy is that here is neo-liberal thinking that debunked governmental interference in the economic activities and glorifies market forces of demand and supply as the best mechanism for allocation of resources and value, using tax payers' money in private driven economy, in the name of bail out. In short 
although the post Keynesian western inspired consensus saw capitalism and liberal democracy as the best option, they have contradicted that postulation.

In fact, the current emphasis on fiscal stimulus elsewhere supports the position that we are back to the Keynesian fundamentals.This is vindicated by the decline in private spending, underway and governments around the world are seeking to replace that with public spending. In other words, the private sector suddenly wants to save more, so the public sector better rush to save less. The big question therefore is, is this not a contradiction?

\section{ORIGIN AND NATURE OF THE GLOBAL ECONOMIC CRISIS}

The Global Economic crisis is not a new phenomena but a periodic manifestation of the cyclical crisis of capitalism vested on the world, conditioned by the difficulties in market forces logic of the liberal and neoliberal thinking. The western countries' adherence to the Euro-American ideocentric preposition with the view of glorifying liberal democracy under the guide of global capitalism as the ideal path to glory has been the root of Global Economic crisis as witnessed in the post first world war, 1920s and 30s, repeated itself in the 1970s and 80 s and the current one the world is still grappling with.

As Momoh and Hundeyin aptly captured:

The major phases of cyclical crisis of capitalism are boom, depression, recovery at an interval of 25 years in capitalist economies. But since the 1970s it has been more acute and occurs at the interval of between 5-10 years (Momoh and Hundeyin, 1998).

From the above preposition it is discernable that accompanying every boom and recovery in the cyclical crisis of a capitalism is economic crisis of today's magnitude. However, western inspired liberal and neo-liberal theorists neither want to hear nor believe in the inadequacies of their prescribed market forces determined economy.

It may be recalled that the Great Depression of the late 1920s and 1930s brought to fore the difficulties in this market force provision of infrastructural facilities and some basic social services. It thus becomes apparent that the market forces neither could adequately account for nor provide for the public goods and effective distribution of resources.

Similarly, the post cold war globalization resulted in the collapse of the Asian tigers economies swamped with capital from global market place (essentially the US and its western allies) resulted from their financial sector openness vulnerability to huge movement of speculative capital. The crash occurred in a domino-like process that began in countries such as South Korea, Taiwan, Indonesia and Singapore, which had initially achieved successfully domestic development through careful state guidance, relied in Thailand and eventually was forced under the heel of IMF agenda.

The collapse of the currencies in the Asian Tigers and the subsequent economic disaster that hit countries such as Indonesia was followed by two further developments; the $17^{\text {th }}$ August 1998 devaluation of the Russian rubble and the January 1999 Brazilian real (UNESCO, 1999). The politics of Globalization seem well on its way. This was a major signal in advance, in the booming Global Economic crisis but nobody seemed to have noticed it (Kly 1999).

Having explored the antecedent to the Great Economic depression, it is germane to state at this juncture that the global financial crisis of fall 2008 and 2011 was unexpected, as only few people predicted that serious problems were looming and even fewer had placed bet accordingly, but even they were astounded by what happened in mid September (Johnson, 2005).

On the weekend of September 13-14, 2008 the US Government declined to bail out Lehman Brothers. The firm subsequently failed i.e. it did not open for business on Monday September $15^{\text {th }}$. Creditors suffered major losses and these had particular negative effects on the markets given that through the end of the previous week the Federal Reserve had been encouraging people to continue to do business with Lehman. Specifically on Tuesday $16^{\text {th }}$ September the Government emergency loaned to the major insurance company, AIG. This was structured so as to become the company's most senior debt and in this fashion, implied losses for AIG's previously senior creditors, the value of their investment. In this A bastion of capitalism dropped 40 percent overnight.

By Wednesday September $17^{\text {th }}$, it was clear that the world financial market funds were in "cardiac arrest". The secretary of the treasury immediately approached the congress for an emergency budgetary appropriation of $\$ 700$ billion (about 5 percent of GDP) to be used to buy up the distressed assets and thus relieve pressure on the financial system (Johnson 2009).

The result of this demand was a rancorous political debate, when the democrat senators queried the wisdom of injecting tax payers' money into private driven economy, culminating in the passing of the so called Troubled Assets Relief Programme (TARP). This not withstanding, the financial and economic situation continues to deteriorate both in the United States and around the world.

Thus began a financial and economic crisis of the first order on a magnitude not seen at least since the 1930s and agreeably with the potential to become bigger than anything seen in the 200 years of modern capitalism. What is not certain however is whether the economic consequences of this phenomenon are merely a severe 
recession or if there will lie a prolonged global slump or worse. The thorny question that demands answer at this point is: what is the deeper cause of this economic crisis? The answer is not far fetched. It was a super sized financial system, the obesity of banks and shadow banks, which help to create the vulnerabilities that made the September crisis possible. The financial system captured its regulation and took in far more risk than it could manage or even understand. This is however, not peculiar to US banks only, but to most parts of the global financial systems.

To capture the essence of the question better, it is safe to resort to the political economy of the US financial system including the poor politics of large financial firms? These grew large relative to the institutions that support and constrain them. In effect an emerging market type structure was created with nothing in the mainstream textbooks or working papers about it. The general working assumption has been that the institutions in the United States were significantly better than in emergency markets, the better time to ask, in what sense is this really true, and is now.

From another perspective, the underlying problem was that after the 1980s the current moderation of volatility in industrialized countries created the conditions under which finance became larger relative to GDP and credit could grow rapidly in any boom (Johnson and Simon 2009).

In addition, globalization allowed banks to become big, relative to the countries in which they are based (Iceland as an extreme example). Financial development, while often beneficial brings risk as will none of those points would have settled with mainstream finance or economic, two years ago; perhaps the consensus around some of these points have shifted recently. Further to that the global economic growth of the last several years was in reality a global debt financial boom with self-fulfilling characteristics like it could have gone on for many years or alternatively collapsed earlier. On the other hand the US housing bubble was inflated by global capital flows, but bubble can as well occur in a closed economy. The European financial bubble including massive lending, to Eastern Europe and Latin America occurred with zero net capital flow (the Euro-zone had a current account roughly in balance). China's export driven manufacturing sector had a bubble of its own. In its case with net capital outflow, a current account surplus).

It must be acknowledged, that regional bubbles were amplified and conned by global financial system that allows capital to flow easily around the world; not that global capital is bad, but ordinarily by delivering capital to places where it is most useful, they promote economic growth in particular in the developing world. Indeed, the global system also allows bubbles on money rise from anywhere in the world; exacerbating global system risk (Johnson 2009). For instance, when billions of dollars were flowing from the richest countries in the world to Iceland, a country of only 320,000 people, chasing high interest rate, the risk of a downturn only magnified for the people of Iceland in particular.

To this end, it is pertinent to say that the prevalence of debt in that global boom was also a major contributing factor to today's recession although major disruption could also arise from the busting of pure discontinuities on the downside, instead of simply losing money companies with high level debt go bankrupt in hard times.

This situation can be contextual located in the case of Lehman, AIG and now GM all created systematic risk to the US and global economy because one default can trigger a series of default among other companies and simply the fear of those dominions falling can have systemic effects. Similarly, emerging market default can have systemic effect by spreading fear and causing investors to pull out of unrelated but similar countries (and causing spectators to set against their currencies and stock markets).

\section{NEO-LIBERAL THEORY OF INTERNATIONAL RELATIONS: A CRITIQUE}

It was stated in the course of this discourse that the western inspired neo-liberal theorists want humanity to believe that there is only one sure way to glory and human aspiration in development and prosperity; the reality however is short of this claim.

The first point for critiquing the neo-liberal thinkers is their consistent unrepentant adherence to the belief that market forces logic is working globally. This market forces logic however has been proved not only unsuccessful but grossly deficient as witnessed in 1920s and 1930s, 1970s and 1980 and currently, which even the neo-liberal thinkers themselves will admit that they need governmental bail out.

It may be recalled that the great depression of the 1920s and 1930s brought to the fore deficiencies in the market forces logic. This gave rise to the establishment of public enterprises for the provision of infrastructural facilities and some basic social services which became apparent that the market forces could neither adequately account for nor provide for public goods and effective distribution of resources. As a result of this there was a major developmental policy shift from the classical to Keynesian and Keynesian school of thought, which believe that state intervention and participation in the economic activities would ensure full employment equilibrium, the control of inflationary gap and general recession. In addition also government intervention is needed to inject money into the economy and embark on monetary and fiscal policies to correct these distortions (Momoh, Hunde, 1995). 
The western inspired conventional thinkers were not comfortable with the Keynesian prescription hence they emerged with neo-liberal theory that still glorifies global capitalism as the end in human ideological evolution. Funny enough, in the wake of the current global economic crisis, the neo-liberal scholars are palpably eating their words through popular vocabulary such as "bail out" or what their experts term as "credible irresponsibility" meaning the use of public funds through government intervention to cushion the effects of the Global financial crisis (Johnson, 2009).

Lamenting on this sad development, the Democratic Senators in the US congress queried the wisdom of injecting tax payers' money into capitalist deregulated economy. The question is what is tax payers' money doing in private driven economy?

Another area of critics of the neo-liberal thinking is the research findings of the Club of Rome and scholars like Samir Amin which argued that:

To the contrary there exist significant analysis of global development suggesting that both the past and present western ideology function to mismanage global issues and process due to the emphasis of western socioeconomic and political ideology on profit, exploitation cultural imperialism or racism and unequal exchange. A stinking instance of this is provided in the recent process of trade liberalization promoted through both the Uruguay Round of GATT, and IMF Structural Adjustment policies, (Kly 1999).

Under the above arrangement while the developing countries have been under pressure so intensive to open up their economies to trade and investment and have largely complied, western countries have failed to follow suit, they continue to maintain tariff barriers which impede the entry to their market of the developing world products such as textiles etc, that is an irony, for example what is the place of made in Nigeria goods in the United States of America market?

Similarly, while these western nations seek unimpeded flow of capital throughout the world, they in general opposed free flow of technology or labour. In this case therefore the former maintain developing world technological dependency, while the other prevent third world population from exercising their market rights to seek out the best price for their labour (Chossudovkey, 1997). The question is how can this neo-liberal claim then favour human aspiration to development and prosperity in the developing countries?

No where did the neo-liberal global capitalism theoretical construct better express its weakness than in the recent research findings of the United Nations. This findings did not support the notion that the globalization of the western liberal market ideologies are required for global human centre development and call attention to what are now quantifiable observed effects of the implementation of this popular concept of globalization on the pursuit of human centered sustainable development. In an article entitled "Globalization with human face" a recent publication of UNESCO raised the issue whether the popular concept of globalization represents a threat to human right.

Another area of critique of the neo-liberal conventional wisdom is that it is a form of post modern jingoism serving the political purpose of encouraging one to associate or confuse the term "globalization" with globalizing negative impact on human centered development. In so doing it hopes to suggest that the consequences of globalizing policies are inevitable, natural and politically neutral phenomena, such as the decrease in the earth's non-renewable resources, popularize growth and technological advancement. This in turn serves as a tool, for distracting the attention from the sources and intent of the socio-economic and political policies under which this development is being produced (Johnson, 2009).

Most importantly the neo-liberal theory to the study of international relations do not provide for ample comprehensiveness to permit silent non-structural formal or legal formal actors and forces in the global system to be adequately discerned for the purpose of identification and socio-economic analysis.

Thus, when international organizations, Multinational Corporation and State governments speak of, or record their formal legal policies as animated or meet by the need of globalization, thus output too often became the point of departure for orientation of studies, analysis and indeed the very definition of international phenomena such as globalization.

Similarly the neo-liberal conventional thinking in the international relations facilitate a focus that seems to permit the seminal ideational influence of such actors, forces and their project to go undetected. As suggested this may be the case in relation to the scholars who focused on popular concept of globalization. The actors, forces and projects which seek to capture the process and product of global development and use them for the purpose of globalizing their economic system, culture; ideologies etc. most often escape attention as politically self interested sources of the content of international relation by scholars who study problematic global development.

Invariably the neo-liberal conventional thinkers have introduced the tendency of doubt talk and spin on the concept of global capitalism with the sole aim of shielding western globalization/globalizing policies under the umbrella of natural globalization. Simply put, it is hoped that the content of western imperialism and neocolonialism will henceforth also be viewed as the content of inevitable, natural process and thus as portrayed in Fukuyama's end of history. 


\section{Conclusion}

This short discussion shows that neo-liberal theory of international relations as voiced out in Fukuyama's end of history and the last man, has outstanding parameters which make the bases of their claim that, global capitalism and internationalization of liberal democracy is an end state of human ideological evolution as not only tautological, but lack sound scientific reasoning; resulting into antinomies and contradictions. Such that their theoretical postulation did not only fail to take mankind to his aspiration of development and prosperity but has accentuated human hope into chaquered and deepening socio-political and economic quagmire unprecedented in human history. Paradoxically, at any time the world is greeted with the cyclical crisis of capitalism occasioned by global crises the resort to the Keynesian prescription of the late seventies, which argued that state intervention is needed to ensure full employment equilibrium, control inflationary gap among others as they did during the 1920s and 1930s and as they are currently doing under the guise of what they termed "credible irresponsibility". Thorny question that demand answer from neo-liberal conventional thinkers is: why is government interfering with private driven economy? Is that not a contradiction to their early claim for non-governmental intervention and participation in the economy? Why are people in the majority of states particularly the Islamic doom seeking for alternative to the failed promises of liberal democratic ideals? Why is it not just the Asian Tigers economy that developed under non-liberal democratic model but also that of America and other European countries are in deep crisis during the epoch of deepening globalization. Getting answers to these seemingly rhetorical questions will certainly shed light on the apparent antinomy of Fukuyama's end of history and the last man.

\section{References}

[1]. Andre Gunder, F. (1981): The Third World in Crisis Holmas and Meier Publishing Inc.

[2]. Basher, K. (1997): The New World Order and Socio Political Transition in Africa in the 1990s and Beyond in B. Caron A. Gboyega and E. Osaghae (eds). Democratic Transition in Africa, Ibadan. CREEDU

[3]. Chossudvsky, M. (1997): The Globalization of Poverty: Impacts of IMF and World Bank Reforms. Third World Network, Malaysia.

[4]. Diamond, L. (1992): "Democracy, "The New War", African Report Sept/Oct.

[5]. Dolmon, A. J. (1977): reshaping the international order, A Report For The Club of Romes

[6]. Lawale, W. A. (1971): "The Military and Future of Democracy in Africa" in O. Omoruyi, D. Berg Schlosser, A. Sambo and A. Okwuosa (Eds) Democratization in Africa. African Perspective, Vol.31, Benin City.

[7]. Fukuyama, F. (1992): The End of History and the Last Man, New York, Oxford University Press.

[8]. Him, P. and Thomson, G. (1996): Globalization in Question.

[9]. Cambridge Polity Press. Hunlington (1991): "Democracy’s Third Wave” Journal of Democracy, Vol. 2(2) Spring. 